\title{
ISOKINETIC DYNAMOMETRY OF KNEE FLEXORS AND EXTENSORS: COMPARATIVE STUDY AMONG NON-ATHLETES, JUMPER ATHLETES AND RUNNER ATHLETES
}

\author{
Cássio Marinho Siqueira, Fábio Ribeiro Mendes Mota Pelegrini, Maurício \\ Furginelli Fontana and Julia Maria D. Greve
}

RHCFAP/3064

SIQUEIRA CM et al. - Isokinetic dynamometry of knee flexors and extensors: comparative study among non-athletes, jumper athletes and runner athletes. Rev. Hosp. Clin. Fac. Med. S. Paulo 57(1):19-24, 2002.

Participation in intensive sports activities leads to muscular specializations that may generate alterations in involved articular forces and cause static (posture) and dynamic changes (alterations of articular stability, coordination, etc.). Prevention of injury requires specific functional muscular evaluation in all athletes and for any kind of sport.

OBJECTIVE: To dynamically evaluate, through isokinetic tests, the peak torque, total work, and average power of the knee flexor and extensor muscles of jumper and runner athletes and compare them to those of a non-athletic population, evaluating dominance and balance between agonistic and antagonistic muscle groups.

RESULTS: In the non-athlete group, we noted a higher asymmetry between the dominant and nondominant members. The jumpers had the highest values of the evaluated parameters of all groups, whereas parameters for the runners were intermediate between non-athletes and jumpers.

DESCRIPTORS: Isokinetic. Muscular strength. Sport. Knee. Muscular balance.

Training and sports practice result in the development of a specific musculature according to the modality practiced $^{1}$. These muscular specializations may initiate an imbalance of the forces acting statically and dynamically on the joints and lead to alterations of posture or of articular mechanics. This muscular imbalance may predispose athletes to injury and reduction of performance ${ }^{2-9}$.

Isokinetic dynamometry is widely used for muscular function studies because it facilitates a dynamic, objective, accurate, and reproducible evaluation. This measurement is feasible for the resistance applied to the movement and can be adapted to permit a constant angular velocity during the whole range of motion; thus, it optimizes the load, which is always the maximum $^{2,3,10-13}$. This evaluation allows us to characterize the muscular alterations resulting from the practice of sports, leading to the improvement of performance, training specificity, and injury prevention.

The objective of this study was to evaluate through isokinetic tests the muscular condition of knees of jumpers (triple and distance) and runner athletes (100 and $200 \mathrm{~m}$ ), and make comparisons within these groups and with a non-athletic population.

From the Department of Orthopedics and Traumatology, Hospital das Clínicas, Faculty of Medicine, University of São Paulo.

\section{METHODS}

Fifty-four volunteers divided into 3 groups-20 runners, 14 jumpers, and 20 non-athletes (Control Group)were evaluated (Table 1). The criteria for inclusion were age between 18 and 30 years, masculine sex, and absence of diseases of the musculoskeletal system. All athletes were training at the competitive level with a minimum training burden of 3 hours daily, 6 days a week. The duration of the sports practice was at least 1 year.

A CYBEX 6000 dynamometer (Lumex, Ronkonkoma) was used for the isokinetic evaluation. All subjects warmed up for 15 minutes on an unloaded ergometric bicycle. After warming up, the subjects were positioned 
Table 1 - Casuistic presentation: age (years), weight $(\mathrm{kg})$, height $(\mathrm{cm})$.

\begin{tabular}{|c|c|c|c|c|c|c|c|c|c|}
\hline & Age & $\begin{array}{l}\text { CONTROL } \\
\text { weight }\end{array}$ & height & age & $\begin{array}{c}\text { UMPERS } \\
\text { weight }\end{array}$ & height & age & $\begin{array}{l}\text { RUNNERS } \\
\text { weight }\end{array}$ & height \\
\hline Average & 19.9 & 71.1 & 174.6 & 20.5 & 74 & 184 & 22 & 73.6 & 179.0 \\
\hline Stand deviation & 1.9 & 10.4 & 7.9 & 1.7 & 8.1 & 5.5 & 4.2 & 6.9 & 7.6 \\
\hline Minimum & 18 & 57 & 160 & 18 & 62 & 177 & 18 & 61 & 157 \\
\hline Maximum & 23 & 105 & 188 & 23 & 89 & 198 & 30 & 90 & 191 \\
\hline $\mathrm{N}$ & 20 & 20 & 20 & 14 & 14 & 14 & 20 & 20 & 20 \\
\hline
\end{tabular}

seated with a $90^{\circ}$ hip flexion on the knee module, aligning the knee movement axis with the dynamometer axis. Three submaximal repetitions were performed for adaptation to the speed. The knee flexor and extensor were tested regarding their concentric activities at the 60 and $240 \%$ second velocities with correction for gravitational force. The evaluated parameters were peak torque (PT), measured in newtonmeters; total work (TW), measured in joules; and average power (POT), measured in watts. All measurements were corrected for the body weight of each individual and were expressed in percentage of that weight. This index, which is suggested by the equipment manufacturer, is widely used in clinical practice and research that employ isokinetic evaluation, helps in the correlation of the parameters evaluated with anthropometric data, and serves as a correction factor ${ }^{14}$. The relationship between the flexor and extensor groups was also evaluated for PT and TW at both velocities. Limbs were grouped according to the dominance given by the side preferably used for the kick. Within each group and for every variable, comparisons were made between the dominant and the nondominant sides. Groups were also compared among themselves for all evaluated parameters as well as for dominance.

Concerning data analysis, a basic statistical study was conducted on ordinal parameters covering average, standard deviation, standard error of mean, maximum and minimum values, and number of cases. Comparisons be- tween the listed parametric ordinal samples (dominant and nondominant members of the same group) were made with the Student $t$ test. For comparisons among more than 2 independent parametric ordinal samples, ANOVA variance analysis was used, and the $t$ test was applied for more specific comparison between groups, assuming different variances. The significance level was $5 \%$.

\section{RESULTS}

Table 2 shows the averages obtained for each group in every parameter evaluated.

When comparing dominant and nondominant limbs within each group, there was a statistically significant difference in the Control Group regarding the flexor PT and TW at $60 \%$. There was also a significant difference in the PT at $240 \%$, with the dominant side being higher than the nondominant. There was also a significant difference in the PT parameter of the flexion/extension relationship of the Control Group. In the Runners Group, there was a significant difference in the power of the extensors, where the nondominant side was higher.

Comparison between the groups showed that the Jumpers Group had significantly higher results than the Control Group in almost all parameters evaluated. The one exception was for the flexor PT and extensor POT of the dominant limb at $240 \%$ s.

The difference of the flexor PT of the nondominant side at both speeds between the Jumpers Group and Control Group was significant. When comparing these two groups regarding extension, differences were found between the PT of dominant and nondominant limbs at $60 \%$ s, and among the PT, TW, and POT of the nondominant limb at $240 \%$ s.

Finally, between the Jumpers Group and Runners Group, there was a significant difference in all flexion parameters, with exception of the flexor PT of the dominant side at both speeds.

\section{DISCUSSION}

The evaluation of human muscular performance has been the aim of many studies, primarily for objective documentation of efficacy of therapeutic procedures for rehabilitation of musculoskeletal system injuries, as well as for identifying deficiencies in muscular strength and determining the relative strength of antagonist muscle groups as they are influenced by dominance. Many authors have tried to establish normative data for muscular evaluation in various populations that might serve to orientate a rehabilitation program and aid in the detection of the causes of musculoskeletal system injuries, thereby facilitating preventive action $^{2-4,11}$.

Isokinetic dynamometry was used for evaluating the muscular performance of jumper and runner athletes. The tests were performed at 2 angular speeds because muscular torque 
Table 2 - Averages of peak torque, total work and average power of knee flexors and extensors corrected for body weight and expressed in \%, and relationship between flexor and extensor muscles for the peak torque and total work parameters at $60 \%$ $\mathrm{s}$ and $240 \%$ speeds of the dominant and nondominant sides in the 3 groups evaluated.

\begin{tabular}{|c|c|c|c|c|c|c|c|c|c|c|c|c|}
\hline & \multicolumn{4}{|c|}{ CONTROL } & \multicolumn{4}{|c|}{ JUMPERS } & \multicolumn{4}{|c|}{ RUNNERS } \\
\hline & \multicolumn{2}{|c|}{$60 \%$} & \multicolumn{2}{|c|}{$240 \% \mathrm{~s}$} & \multicolumn{2}{|c|}{$60 \%$} & \multicolumn{2}{|c|}{$240 \% \mathrm{~s}$} & \multicolumn{2}{|c|}{$60 \%$} & \multicolumn{2}{|c|}{$240 \% \mathrm{~s}$} \\
\hline & D & ND & D & ND & D & ND & D & ND & D & ND & D & ND \\
\hline \multicolumn{13}{|l|}{ FLEXION } \\
\hline Peak torque (\%BW) & 185.1 & 173.6 & 128.5 & 114.9 & 226.2 & 221.7 & 145.9 & 147.7 & 200.4 & 197.1 & 133 & 129.7 \\
\hline Total work (\%BW) & 201.7 & 187 & 122 & 112.2 & 242.9 & 226.2 & 151.2 & 148.5 & 211.4 & 206.5 & 125.7 & 124.4 \\
\hline Average power (\%BW) & & & 306 & 278.7 & & & 379.6 & 371.1 & & & 306.5 & 306.9 \\
\hline \multicolumn{13}{|l|}{ EXTENSION } \\
\hline Peak torque (\%BW) & 315.1 & 311.5 & 180.7 & 177.8 & 373.9 & 372.1 & 221 & 218.3 & 349.1 & 347.9 & 197.4 & 204.9 \\
\hline Total work (\%BW) & 302.1 & 301.7 & 175.4 & 170.1 & 345.9 & 344.2 & 206.9 & 209 & 311.8 & 310.5 & 186.4 & 197.8 \\
\hline Average power (\%BW) & & & 449.7 & 427 & & & 512 & 515 & & & 437.2 & 489.6 \\
\hline \multicolumn{13}{|l|}{ FL/EXT } \\
\hline Peak torque (\%) & 58.3 & 55.7 & 70.3 & 62.6 & 60.7 & 60 & 66.2 & 67.7 & 56.7 & 56.2 & 65.5 & 63.1 \\
\hline Total work (\%) & 65.9 & 62.1 & 66.6 & 67.3 & 70 & 66.2 & 73.2 & 72 & 66.3 & 65.3 & 66.8 & 63.5 \\
\hline
\end{tabular}

$\mathrm{D}=$ dominant $; \mathrm{ND}=$ nondominant $;(\% \mathrm{BW})=$ absolute values of parameters corrected by the body weight and expressed as percentage of the latter

Table 3 - Statistical probability $(P)$ values in the comparison between the dominant and nondominant limbs of each group at the 2 testing speeds (60 and $240 \%$ s).

\begin{tabular}{lllllll}
\hline & \multicolumn{2}{c}{ CONTROL } & \multicolumn{2}{c}{ JUMPERS } & \multicolumn{2}{c}{ RUNNERS } \\
& $60 \%$ s & $240 \% \mathrm{~s}$ & $60 \%$ & $240 \% \mathrm{~s}$ & $60 \%$ & $240 \% \mathrm{~s}$ \\
\hline FLEXION & & & & & & \\
Peak torque (\%BW ) & $0.009^{*}$ & $0.044^{*}$ & 0.43 & 0.72 & 0.357 & 0.64 \\
Total work (\%BW) & $0.009^{*}$ & 0.07 & 0.09 & 0.66 & 0.238 & 0.88 \\
Average power (\% BW) & 0.06 & & 0.66 & & 0.99 & \\
EXTENSION & & & & & & \\
Peak torque (\%BW) & 0.67 & 0.54 & 0.88 & 0.68 & 0.87 & 0.3 \\
Total work (\%BW) & 0.956 & 0.23 & 0.68 & 0.74 & 0.85 & 0.81 \\
Average power (\% BW) & 0.11 & & 0.89 & & $0.048 *$ & \\
FL/ EXT & & & & & & \\
Peak torque (\%) & 0.172 & $0.0001^{*}$ & 0.8 & 0.63 & 0.7 & 0.46 \\
Total work (\%) & 0.08 & 0.8 & 0.25 & 0.75 & 0.5 & 0.41 \\
\hline
\end{tabular}

$(\% \mathrm{BW})=$ absolute values of parameters corrected by the body weight and expressed as percentage of the latter; *significant difference $(P<.05)$.

(strength) must be evaluated at lower velocities $(60 \%)$, and power at a high velocity $(240 \% \mathrm{~s})^{2-4,11}$. When evaluating both speeds, the muscular specialization of the individual can usually be better observed as the sports activities are performed at high velocities.

Our results showed significant differences between dominant and nondominant limbs only in knee flexors of the Control Group, where the dominant side is stronger than the nondominant.
Concerning the knee extension of the non-athletic group, at $60 \%$ in all evaluated parameters, the dominant limb had averages higher than the nondominant one, though not reaching levels of statistical significance. These results show that there is a small tendency towards asymmetry with prevalence of the dominant side, which was defined in this study as the side preferred for kicking.

Concerning extensor power (POT), the Runners Group had significantly higher scores on the nondominant side, and the Jumper Group had a tendency towards higher scores with the nondominant-side extensors. These differences may be related to the prevailing function of each limb in locomotion. The nondominant limb has a higher support function, requiring greater action of the knee extensors in absorbing power (to restrain movements) in relation to the other leg during the mean stance phase. The dominant leg has a propulsion function, and during the final stance phase, greater muscular activity and high power development occurs in the hip and ankle compared to that in the nondominant limb ${ }^{9,15}$.

Therefore, we believe that since the activity of these athletes is related to locomotion at high speeds, the performance in the nondominant side in the $240 \%$ s tests was superior to that of the dominant side because of the greater muscular action occurring in the knee of the supporting limb. This difference in the predominant functions of the limbs would not have much importance for the non-athletes, since running is not the primary motor activity contributing to their acquisition of 
Table 4 - Statistical probability $(P)$ values in the comparison among the groups at the 2 testing speeds.

\begin{tabular}{|c|c|c|c|c|c|c|c|c|c|c|c|c|}
\hline & \multicolumn{4}{|c|}{ Control x Jumpers } & \multicolumn{4}{|c|}{ Control x Runners } & \multicolumn{4}{|c|}{ Runners x Jumpers } \\
\hline & \multicolumn{2}{|c|}{$60 \%$} & \multicolumn{2}{|c|}{$240 \% \mathrm{~s}$} & \multicolumn{2}{|c|}{$60 \% \mathrm{~s}$} & \multicolumn{2}{|c|}{$240 \% \mathrm{~s}$} & \multicolumn{2}{|c|}{$60 \%$} & \multicolumn{2}{|l|}{$240 \% \mathrm{~s}$} \\
\hline & D & ND & D & ND & D & ND & D & ND & D & ND & D & ND \\
\hline \multicolumn{13}{|l|}{$\begin{array}{l}\text { FLEXION } \\
\end{array}$} \\
\hline Peak torque (\% BW) & $0.004 *$ & $0.0005 *$ & 0.09 & $0.0001 *$ & 0.068 & $0.001 *$ & 0.64 & $0.04 *$ & 0.058 & $0.047 *$ & 0.25 & $0.023 *$ \\
\hline Total work (\% BW) & $0.006 *$ & $0.005^{*}$ & $0.01 *$ & $0.0001 *$ & 0.34 & 0.056 & 0.67 & 0.17 & $0.036^{*}$ & $0.005^{*}$ & $0.033 *$ & $0.012 *$ \\
\hline Average power (\% BW) & & & $0.01 *$ & $0.0001^{*}$ & & & 0.98 & 0.21 & & & $0.001 *$ & $0.01 *$ \\
\hline \multicolumn{13}{|l|}{ EXTENSION } \\
\hline Peak torque (\% BW) & $0.01 *$ & $0.005^{*}$ & $0.002 *$ & $0.001 *$ & $0.006^{*}$ & $0.003 *$ & 0.09 & $0.002 *$ & 0.24 & 0.22 & 0.065 & 0.24 \\
\hline Total work (\% BW) & $0.01 *$ & $0.047 *$ & $0.01 *$ & $0.003 *$ & 0.32 & 0.37 & 0.22 & $0.002 *$ & 0.054 & 0.1 & 0.11 & 0.37 \\
\hline Average power (\% BW) & & & 0.12 & $0.008^{*}$ & & & 0.63 & $0.012 *$ & & & 0.078 & 0.43 \\
\hline \multicolumn{13}{|l|}{ FL/EXT } \\
\hline Peak torque $(\%)$ & 0.37 & 0.15 & 0.16 & 0.1 & 0.53 & 0.85 & 0.22 & 0.88 & 0.15 & 0.2 & 0.85 & 0.24 \\
\hline Total work (\%) & 0.19 & 0.25 & 0.1 & 0.29 & 0.87 & 0.3 & 0.95 & 0.45 & 0.25 & 0.79 & 0.23 & 0.11 \\
\hline
\end{tabular}

$\mathrm{D}=$ dominant; $\mathrm{ND}=$ nondominant; $(\% \mathrm{BW})=$ absolute values of parameters corrected by the body weight and expressed as percentage of the latter; *significant difference $(P<.05)$.

muscular strength; other activities that require more muscular action of the dominant-side knee are more significant for them.

When comparing the groups, we found that in almost all parameters studied, even when the differences were not statistically significant, the averages for the Jumper Group were always higher, followed by the Runner Group, and then by the Control Group.

The Jumper Group surpassed the Control Group in practically all parameters evaluated, demonstrating two distinct groups as to the muscular performance in the knee joint. The Runners Group had scores that were between those of the other two groups. Runners are athletes characterized by developing high values of peak torque, which however, decreases rapidly during the range of motion, as seen through evaluation of the total work. They had higher scores in the extensors than in the flexors. Thus, the runners' extensors are equal to those of the jumpers, and the flexors are equal to those of the controls, being superior only at PT.

These results have practical importance because these athletes are frequently thought to constitute a homogenous group, since the modalities have similar characteristics, and some ath- letes even practice two types of sports. However, by the dynamic muscular characteristics, these groups are different and require a more specific approach.

No significant differences were found in the comparison of the groups as to the relationships between flexor and extensor musculature; muscular balance is statistically equal in the 3 groups. However, if we analyze the averages of this relationship regarding the peak torque, we shall find that the jumpers constitute the most "balanced" group while, the runners are the most "imbalanced", and the controls are intermediate between these groups. But, if we analyze this relationship regarding the total work, the runners appear "more balanced" than the Control Group.

The relationship between antagonistic muscles is controversial ${ }^{2-5,12,16-18}$. This relationship is traditionally defined as dividing the strength of the weaker muscle by that of the stronger one when both are in concentric activity. This approach has been criticized for not being functional ${ }^{19}$, since the antagonistic muscle acts eccentrically and also because when considering the peak-torque relationship, we are measuring 2 different points of the move- ment range. Even so, many authors relate this muscular imbalance to injuries, while others think that this evaluation cannot be made with the existing data. Baratta and Solomanow ${ }^{5}$ demonstrated that the action of the hamstring as an antagonist is intimately connected with its concentric action; that is, its antagonist action is directly proportional to its capacity to generate force concentrically. We thus believe that the form traditionally used for measuring the relationship between muscles gives us an idea about the relationship of forces acting over the joints, and we therefore can propose preventive and therapeutic actions.

\section{CONCLUSIONS}

- The dominance factor is only significant for non-athletes. Athletes tend to have symmetric limbs and greater performance of the nondominant side at high speeds.

- The groups differ among themselves; jumpers have higher averages in all parameters.

- Runners are characterized by having a high peak torque that is not maintained for total work. Their extensor muscles perform better than 
those of non-athletes, which is not true of the flexor muscles.

- There are no differences among the groups regarding the relationship between flexors and extensors.

\section{FINANCIAL SUPPORT}

- Scholarship for initial Scientific research from the State of São Paulo Foundation for Scientific Research
Support (FAPESP): Cássio Marinho Siqueira.

- Additional support from the above foundation: Pentium III computer.
SIQUEIRA CM e col. - Dinamometria isocinética de flexores e extensores de joelho: comparação entre atletas saltadores, velocistas e grupo não atleta. Rev. Hosp. Clín. Fac. Med. S. Paulo 57(1):19-24, 2002.

A prática esportiva leva às especializações musculares que podem gerar alteração nas forças atuantes articulares e causar alterações estáticas (postura) e dinâmicas (alteração da estabilidade articular, alteração da coordenação, etc.).
A prevenção de lesões deve ser feita através de uma avaliação funcional muscular específica em todos os atletas e em qualquer modalidade esportiva.

OBJETIVO: Avaliar dinamicamente, por testes isocinéticos, o torque máximo, o trabalho total, e a potência média dos músculos flexores e extensores do joelho de atletas saltadores e velocistas, comparando-os com uma população não atleta em relação à dominância e equilíbrio entre agonistas e antagonistas.
RESULTADOS: Nota-se maior assimetria entre os membros dominante e não dominante no grupo de não atleta. Entre os grupos verifica-se que os saltadores têm valores maiores dos parâmetros avaliados, os velocistas têm parâmetros intermediários entre os não atletas e saltadores.

DESCRITORES: Isocinético. Força muscular. Esporte. Joelho. Equilíbrio muscular.

\section{REFERENCES}

1. SCRANTON Jr PE, WHITESEL JP \& FAREWELL V - Cybex evaluation of the relationship between anterior and posterior compartment lower leg muscles. Foot Ankle 1985;6:85-89.

2. OSTERNIG LR - Isokinetic dynamometry: implications for muscle testing and rehabilitation. Exerc Sport Sci Ver 1986;14:45-80.

3. PERRIN DH - A brief introduction to isokinetics. In: PERRIN DH Isokinetic exercise and assessment. Champaign, IL, Human Kinetics Pubs, 1993. p.1-9.

4. OSTERNIG LR, HAMILL J, LANDER JE et al. - Co-activation of sprinter and distance runner muscles in isokinetic exercise. Med Sci Sports Exer 1986;18:431-435.

5. BARATTA R, SOLOMONOW M, ZHOU BH et al. - Muscular coactivation. The role of the antagonist musculature in maintaining knee stability. Am J Sports Med 1988;16:113-122.

6. GRACE TG - Muscle imbalance and extremity injury. A perplexing relationship. Sports Med 1985;2:77-82.
7. GOSLIN BR \& CHARTERIS J - Isokinetic dynamometry: normative data for clinical use in lower extremity (knee) cases. Scand J Rehab Med 1979;2:105-109.

8. VAN MENCHELEN W - Running injuries. A review of the epidemiological literature. Sports Med 1922;141:320-335.

9. CANAHM H \& ELLIOTT D - Pedal asymmetry in the reproduction of spatial locations. Cortex 1987;23:157-159.

10. ELLIOT J - Assessing muscle strength isokinetically. JAMA 1978;240:2408-2410.

11. IMAMURA M - Avaliação isocinética dos pés de homens adultos normais. São Paulo, 1994. (Tese - Faculdade de Medicina, Universidade de São Paulo).

12. KANNUS P - Isokinetic evaluation of muscular performance: implications for muscle testing and rehabilitation. Int J Sports Med 15;(Suppl. 1) p.11-8. 
13. MOFFROID M, WHIPPLE R, HOFKOSH J et al. - Study of isokinetic exercise. Phys Ther 1969; 49:735-749.

14. FERNANDES TBF \& SHINZATO GT - Avaliação isocinética de rotadores externos e internos do ombro de atletas sobre cadeira de rodas e indivíduos sedentários - estudo comparativo. Acta Fisiátrica, 1999; 6(1):40-44.

15. SADEGHI H, ALLARD P \& DUHAIME M - Functional gait asymmetry in able-bodied subjects. Human Movement Science 1997; 16:243-258.

16. PÉCINA M \& BOJANIC I - Overuse injuries of the musculoskeletal system. Boca Raton, CRC Press, 1993.
17. SOMMER HM - Patellar chondropathy and apicitis, and muscle imbalances of the lower extremities in competitive sports. Sports Med 1988;5(6):386-394.

18. PIEPER HG, SCHNEIDER A \& WOLF U - Muscular imbalance in elite swimmers and resulting sports damage of the lumbar spine and knee joints. Sportverletz Sportschaden 1989; 3(1):29-31.

19. CALMELS PM, NELLEN M, VAN DER BORNE et al. - Concentric and eccentric isokinetic assessment of flexor-extensor torque ratios at the hip, knee, and ankle in a sample population of healthy subjects. Arch Phys Med Rehabil 1997; 78(11):1224-1230.

Received for publication on January 23, 2001. 